\title{
Social Media as a Means to Enhance Business Performance
}

\author{
Nurul Ain Abdullah ${ }^{1 *}$, Mohd Khata Bin Jabor ${ }^{1}$, Mohamad Alif Ismail ${ }^{1}$, Ahmad \\ Shobah Mohd Isa ${ }^{1}$, Hanim Zainal ${ }^{1}$
}

${ }^{I}$ Faculty of Social Sciences and Humanities, Universiti Teknologi Malaysia, 81310 UTM Johor Bahru, Johor. *Corresponding Author. Email: mkhata@utm.my

\begin{abstract}
Social media like Facebook, Twitter, Instagram, G Plus, Tumblr and Blogs have been used widely in business nowadays and it grows day by day especially when customers can purchase the products just by one click. Therefore, this study is designed to briefly review the use of social media on promoting business, based on the analysis of the relevant literature review in this field. The main purpose of this paper is to identify various social media used for promoting business, the relevance of using social media in promoting business and also to find out the factors for customer's attraction towards purchasing online. The method used in this study is by referring to the secondary sources like ejournal, books and also thesis. The information from these secondary sources were searched and analysed based to the objectives and issues of this study. For the overall conclusion, the findings shows that there are a lot of social media used in promoting business like Facebook, Flickr, Groupn, twitter and others. However, the social Facebook has dominated others. Other than that, from this study it shows that the social media is a relevant medium to promote business as the social media very popular among the society around the world. Social media is also able to approach customers with interactive objectives such as conversation, sharing and able to persuade the customers. The findings from this study may help the sellers to plan their business well especially by promoting their products or services using social media.
\end{abstract}

Keywords: Business, Mobile application

\section{INTRODUCTION}

Communication, networking, and content sharing have become widely developed in the social media space. This platform has been used by many companies to seek marketing and business opportunities even if there are still some issues on resources generated from these sites and business performances that are still remain unexploited. As according to Weinberg \& Pehlivan [1], basically the increases of revenue of using social media in promoting business is the same way as traditional marketing, in which it is aimed to increase the company's products or services by heightening notoriety.

As been stated by Paniagua \& Sapena [2], social capital, social corporate networking, social marketing and revealed preferences are the four channels provide by social media that affects business performances. This article by the way contributes to an issue of the use of social media in promoting business in which it will go through three objectives mainly the various social media used in promoting business, the relevance of using social media in promoting business and factors for customers of purchasing online.

Before discussing further on the use of social media in promoting business, it is important to look at past researches that have been done on this issue. Husson et al. [3] stated that digitalization of media in our society gives the companies out there the most profound effect in their marketing strategies and this holds across all studied sectors. Social media like Facebook, Twitter, Instagram, G Plus, Tumblr and Blogs have been used widely in E-commerce business nowadays and it grows day by day especially when customers can purchase the products just by one click. Rawat \& Divekar [4] admitted that social media has become a stepping stone for everyone to started promoting their products and services as it is easily accessible to anyone with internet access and it is inexpensive for any marketer to implement marketing campaign.

According to Oh [5] the widely known brands are often contemplated, known and consequently chosen by the customers as compared to unknown brands/products/services. It is hard for some who are just setting up a new business line, especially for those who starts as a small business. Thus by using social media, it is believes that a wider crowd can be established and Oh [5] also stated that those who are involve in business but never get to link with social media as a tool of promoting their business are left behind in terms of technology and business. The impact of social media in promoting business is proved by Dolen \& Verhagen [6] that the costumers 
often impulsively triggered when purchasing online as it is easy for them to access to the products, easy purchasing and lack of social pressures. Social pressure here carries the meaning of self-pressure on impulse buying behavior and surrounding pressure like making a decision while being followed by the sellers.

Since social media is so influential in engaging customers with the sellers in terms of purchasing products and services, thus the researchers are interested to conduct a research regarding the use of social media in promoting business. The researchers will focus on three part that are included in the objectives stated which are various of social media used in promoting business, the relevance of using social media as a tool for promoting business and the factors of why customers tend to purchasing online.

\section{LITERATURE REVIEW}

\subsection{Various Social Media Used for Promoting Business}

'Social Media' concept is a uniting of the 2.0 version of World Wide Web that has become the medium for collaborative projects, forming of virtual community, socializing networks, blogs and microblogs, free websites and group games. According to the researcher Kaplan and Haenlein [7], the revolution of social media is not only on the way to social communication tool but it also seen in the business environment due to the amazing speed in which it enters the various world from business, communication, economic and social. Through social media, information are transferred incredibly fast, cost-free and can be reached by everyone around the world.

Smith [8] presented a list of social media with the number of users of top services and its impact on the economic environment. The results are summarized as followed:

Table 1: Statistics of Users Using Social Media Per

Month

\begin{tabular}{|l|l|l|}
\hline No. & $\begin{array}{l}\text { Type of Social } \\
\text { Media }\end{array}$ & $\begin{array}{l}\text { Number of Users } \\
\text { (Millions/ Month) }\end{array}$ \\
\hline 1. & Facebook & 1190 \\
\hline 2. & Flickr & 87 \\
\hline
\end{tabular}

\begin{tabular}{|l|l|l|}
\hline 3. & Gmail & 425 \\
\hline 4. & Groupon & 43 \\
\hline 5. & Wordpress & 66 \\
\hline 6. & Blogspot & 45 \\
\hline 7. & Youtube & 100 \\
\hline
\end{tabular}

Starting from these statistics, Smith proved that the impact on social media on business build along the way with the growing of the number of users. It is incredibly fantastic as such small thing could generates on a greater frames of business marketing.

Moreover, the way social media is easily accepted environment and friendly created such a way for the customers and seller to easier communicating and it's opening channel for networking from multiple experiences. The increasing of productivity by a particular product/service seller in a way that it is collaborated with social media. Various social media stated and investigated by the researcher from previous researches have proved that multiple social media can be used for promoting business. Technologies are undeniably give positive impact towards the vector of changes in the economic world. Customers are now have the chance of choosing the variety of social media out there in order to purchase products and services or to seek for other people review on those particular products.

\subsection{The Relevance of Using Social Media in Promoting Business}

Social media become popular among society nowadays. Most of the people regardles of their life background and also ages prefer to have their own social media account. It is not only in our country but the people around the world like to associate using social media. There are billion users of social media Facebook in worldwide. There are $70 \%$ of the population in USA, Europe and also India are the users of atleast one type of social media. They use their social media not only for socialize but they prefer to survey products or something to purchase just using the social media. Knowing the growing popularity of social media, the business promoting pattern has shifted from traditional e-commerce to the social commerce. Since this medium is very popular among the society around the world, this is the good opportunity that should be grabbed to develop business or to promote their products

In order to make customers purchase certain product, the trust from the customers is the important thing. Most of the marketers are trying to build customers' 
trust by advertising their products and the social media is one of the medium that can create customers' trust and can reach them easily at a low cost. Social media is a fantastic medium for advertising products as the viral feature in this medium may help to attract the customers' attention and trust. Making viral is a trend among the social media users. It is normal for the social media users to make viral for the things that they like most; perhaps they like to viral or promote the products that they like and use just by clicking a button in the social media. This viral features may attract others user to try and trusting the products.

The main activity in social media is to interact with each other. The user used social media to socialize and keep in touch with others user. Once the marketer used this social media to promote their business it might make the customers more attract to the products as it make them easier to interact in order to get information or details about the product. By using the medium, the founder or the seller can deepen their connections with the customers. Customers may ask the details of the product straight away from the seller while the seller able to explain the product effectively. The sellers are able to get great audience and able to have continuous interaction with them. Additionally, by using this social media the sellers are able to persuade their future customers directly. Social networks are able to approach customers with interactive objectives such as conversation, sharing, and engagement Weinberg \& Pehlivan, [1].

By interacting in the social media, the consumers able to observe the others customers purchase behaviors and decision. As according to the observational learning theory by Bandura, the individuals behavior could affected by observing others behavior either in positive or negative ways. Hence, by applying this theory, the studies have proved that the previous consumers can shape the current consumers' productadopting decisions. [16]. The decision of the current consumers to buy or not to buy the product is obtained from the review or opinion from others' customers. 9]. Thus, it is no doubt that observing customers' purchase is a vital element that influences consumers' decision making process. Therefore, the use of social media is significant in developing an online review or testimony from the previous consumer that indicate the effectiveness or quality of the products as gain more consumers in the future, Zheng, Zhu \& Lin [10]

\section{METHODOLOGY/MATERIALS}

For this study, the secondary sources were used in obtaining the data. The data were obtained by referring to the e-journal and books that related to the topic of the study. The information and data regarding the topic were assessed by using the internet through the google search engine that can assessed at http://www.google.com/. The subscribed journal such as Science Direct was assessed by using the Universiti Teknologi Malaysia (UTM) website. The key words used in the literature search were social media, social commerce, promoting business, and online business. There were also hand search for the books and thesis at the UTM's library shelf. The information from these secondary sources were searched and analyzed based to the objectives and issues of this study.

\section{RESULTS AND FINDINGS}

In recent years, the shifting of purchasing products or services from traditional paradigms to social commerce has accelerated from day to day. Based on the research on the literature review that we have, there are three major factors that attracts customers towards purchasing online. The first one is stated by Wang et al. [11] that social sellers influence in which the online sellers who have certain characteristics like popularity, integrity in business, social influence and affective social skills tend to be succeeded in their business. It is indeed true where we can see that mostly the online sellers are those who are already have achieved social popularity in the community. This has been supported by Rawat \& Divekar [4] which added a point where they stated that even if the sellers do not have the attention of the customers in some way, they may use a strategy where choosing public figure to promote their products and services. This is commonly happen nowadays especially when public figures who have many followers on social media tend to make business by promoting other sellers business. The impact of social media influence on the customers is not really surprising with the growth of sellers who are already famous on this so called virtual world.

Second is customers' involvement in reviewing the product or services. In the finding of our first objective has stated that the variety of social media today have a place for customers to drop comments and writing their review on that particular products or services. This has been supported by Dolen \& Verhagen [6], where they found out based on their online survey that customers' role in the conceptually reviewing the products online has been one of the major factor that attracts other customers towards that particular products. They came up with the example of purchasing fashion goods online that has become a typical hedonic among most of the online users nowadays. They stated that the online stores tend to view their customers good reviews to attract more customers and show representational delights of positive feedback from their previous customers.

The third factor is brand boundary which means most of the products and services nowadays accelerated in their marketing strategies by creating brand boundary by convincing the customers that they are the best brands on the market compared to other brands which did not appear online. As been stated by Parmentier \& Mangematin [12], customers tend to purchase products especially via social commerce is because 
they believe that brands which appear online are better than that in the market.

Nowadays the impact of Social Media towards business marketing of the contemporary organizations can be witnessed on managerial, marketing and ICT level. The most used services on the internet is socializing environment in which it leads to obvious advantages on the companies in promoting their product and services to the customers. Informational capitalization is supported by the social media by spreading the information about the companies easily and reaching those who have interest in the products or services they offer. It is good to have social media as a tool for promoting business because it give a space for customers or potential customers to leave feedbacks about the products/services of that particular company. It gives people the opportunity to express their views like in Facebook, the users may show their likes and post comment or even share it that may broaden the business promotion. Like, comment and share button on Facebook are indeed play important roles in business promotion.

As been showed in the finding parts earlier on, we have discussed three major aspects in business promotion that related with social media which are the variety of social media used, its relevance and the factors for customers' attraction towards purchasing online. Based on the literature that we have done, we have achieved all of our objectives where we have come up with evidence of past researches. Social media like Facebook, Blogspot, Twitter, Flickr, Youtube and others are all been used by the customer around the world to look for products and services online. Based on the research that been done $\mathrm{Yu} \&$ Wang [13], a survey on Dell computer company shows that, after their debut on Twitter in promoting their computer business, they earned 6.5 million dollars within a week, where they have almost 1.5 million adepts. Starting from a well-targeted publicity, the company posted oriented advertisements based on data from the users' profiles on different websites in which they managed to reach those who might have interest in buying their products. Constant, diligent and consistent feedback have force this company to use social media as a channel for marketing strategies.

\section{CONCLUSION}

Entrepreneurship is the medium that spurs the creativity and innovation. Successful entrepreneur require a special value added from some combination of creative idea and a superior capacity for a successful journey in business venture. Creativity and innovation creates new demand and entrepreneurship brings the innovation to the market. Creativity and innovation are the heart of the spirit of enterprise which means both are play a vital role to strive the successful and viable enterprise. The organization and market product need the touch of creativity and innovation in order to not leave behind especially in competitive market nowadays. Creativity has always been closely linked to innovation by McLean that organization must nourish creativity and innovation in entrepreneurship for many reasons.

There is no doubt that current economics are volatile and violent one. Entrepreneurs need to ensure the organization are continue to delight the customer, produce the product in accordance to requirement which is the purpose of every business. To grow prosper most enterprise constantly need to improve their product and services. The innovative elements should continuously change to fulfil one's need also for the survival of the enterprise. Entrepreneurs who embrace creativity and innovation in their business models, will be moving forward and be successful than entrepreneurs who remain with the traditional business model, which is only concerned with selling exclusively. The value of creativity and innovation generating the new ideas in business attract more benefits and value added towards the companies. Creativity and innovation are no longer doubt in purposes to help in keeping the business running for a long time and stay competitive.

\section{REFERENCES}

[1] Weinberg, B. D., \& Pehlivan, E. (2011). Social spending: Managing the social media mix. Business Horizons, 54(3), 275-282.

[2] Paniagua, J., \& Sapena, J. (2014). Business Performance and Social Media: Love or Hate? Kelley School of Business, 57(8), 719-728. Indiana University: Valencia, Spain.

[3] Husson, T., Ask, J. A., Overby, C. S., Parrish, M., Mullen, A. McCarthy, J. C., Roberge, D., \& Kwan, E. (2013). Mobile Trends for Marketers. Forrester.

[4] Rawat, S. \& Divekar, R. (2014). Developing a Social Media Presence Strategy for an E-Commerce Business. Economic and Finance, 89(11), 626-634. Institute of Management Studies.

[5] Oh, H. (2000). The Effect of Brand Class, Brand Awareness, and Price on Customer Value and Behavioral Intentions. Journal of Hospitality and Tourism Research, 24(2), 136-162.

[6] Dolen, W., V. \& Verhagen, T. (2011). The Influence of Online Store Beliefs on Consumer Online Impulse Buying: A Model and Empirical Application. Information and Management, 48(3), 320-327. University of Amsterdam Business School: Netherlands.

[7] Kaplan, A. \& Haenlein, M. 2010. Users of The World, Unite! The Challenges and Opportunities of Social Media in Business Horizon. Paginile, 59-68, retrieved 
http://www.sciencedirect.com/science/article/pii/S000 7681309001232.

[8] Smith, C. (2013). How Many People Use 340 of the Top Social Media, Apps and Tools? Retrieved at http://expandedramblings.com/index.php/resourcehow-many-people-use-the-top-socialmedia/\#.UslEHNJdVmg.

[9] Chen, P. Y. S., \& Hitt, L. M. (2002). Measuring switching costs and the determinants of customer retention in Internet-enabled businesses: A study of the online brokerage industry. Information Systems Research, 13(3), 255-274.

[10] Zheng, Y., Zhao, K., \& Stylianou, A. (2012). The impacts of information quality and system quality on users' continuance intention in information-exchange virtual communities: An empirical investigation. Decision Support Systems, 56,513-524.

[11] Wang, Y., Hsiao, S. H., Yang, Z. \& Hajli, N. (2016). The Impact of Social Sellers' Influence on the Co-creation of Innovation with Customers and Brand Awareness in Online Communities. Industrial Marketing Management, 54(3) 56-70. South National Avenue: USA.

[12] Parmentier, G., \& Mangematin, V. (2014). Orchestrating Innovation with User Communities in the Creative Industries. Technological Forecasting and Social Change, 83, 40-53.

[13] Yu, C. \& Wang, Y. (2015). Social Interactionbased Consumer Decision-making Model in Social Commerce: The Role of Word of Mouth and Observational Learning. Journal of Information Management, 147(11), 401-417. National Chengchi University: Taiwan. 